\title{
Growth Inhibition and Apoptosis Induction of Essential Oils and Extracts of Nepeta cataria L. on Human Prostatic and Breast Cancer Cell Lines
}

\author{
Seyed Ahmad Emami ${ }^{1}$, Javad Asili ${ }^{1}$, Shima HosseinNia ${ }^{2}$, Rezvan Yazdian-Robati ${ }^{3}$, \\ Mehrdad Sahranavard ${ }^{1}$, Zahra Tayarani-Najaran ${ }^{2 *}$
}

\begin{abstract}
Nepeta cataria L. has been used in traditional medicine of some countries. Here the cytotoxic and apoptogenic activity of methanol extracts, n-hexane, dichloromethane, ethyl acetate, n-butanol, and acqueous extracts and the essential oil obtained from the aerial parts of the plant were evaluated with PC3, DU-145 and MCF-7 cell lines. Cell viability, histograms of PI stained fragmented DNA in apoptotic cells and Western blot analysis of proteins involved in the cascade of apoptosis were compared in all samples. Thirty components were identified as volatile, representing $99.7 \%$ of essential oil composition after GC-MS analysis of the oil obtained from aerial parts of the N. cataria by hydrodistillation. The major oil components of the essential oil were nepetalactone stereoisomers. Comparing IC50 values showed estrogen receptor positive PC3 cells were more sensitive to the cytotoxic effects of N. cataria in comparison with low hormone-receptor presenting DU-145 cells. Among multiple extracts and essential oils of the plant, only the ethyl acetate extract could significantly decrease cell viability in PC3 cells, in a concentration dependent manner. Ethyl acetate extract of N. cataria treated cells showed a sub-G1 peak in PC3 cells in a concentration dependent manner that indicates the involvement of an apoptotic process in ethyl acetate extract-induced cell death. Western blotting analysis showed that in PC3 cells treated with ethyl acetate (48 h) caspase 3 and PARP were cleaved to active forms. Overall, the results suggest that further analytical elucidation of N. cataria in respect to finding new cytotoxic chemicals with anti-tumor activity is warranted.
\end{abstract}

Keywords: Nepeta cataria L - lamiaceae - cytotoxic - apoptosis - essential oil

Asian Pac J Cancer Prev, 17, Cancer Control in Western Asia Special Issue, 125-130

\section{Introduction}

Nepeta is a genus belonging to the family of Lamiaceae, including approximately 250 species. There are 79 species of this genus found in Iran (Jamzad, 2012) of which 38 species are endemic to the country (Emami \& Aghazari, 2011). Nepeta cataria L. (catnip), is a short herbaceous perennial, growing $27-100 \mathrm{~cm}$ tall and wide. It has the square stem with brown-green foliage. The coarse-toothed leaves are triangular to ovate. The species has white flowers with fine purple spots and a strong aromatic odor. This plant is grown in Asia and Southeast Europe. It is distributed in north, northwest, northeast, west and center of Iran (Jamzad, 2012). Nepeta cataria is antipyretic, antispasmodic, sedative, diuretic and diaphoretic (Duke, 2001). Previous studies reported that therapeutic properties of Nepeta species are due to the presence of essential oil (EO) and flavonoids in the plant. Nepeta lactones and its isomers are the main constituents of the EO of N. cataria (Baser et al., 2000; Safaei-Ghomi et al., 2009).

Apoptosis or programmed cell death is the hemostatic process that controls cell population in normal tissues and in many disease conditions such as ischemic damage, autoimmune disorders and in different types of cancer. Apoptotic cells display some modification such as DNA breakdown, cleavage in proteins and over express of caspases that trigger proteolytic cascade and lead to cleavage of several main proteins that are essential for cell survival (Elmore, 2007). PARP is one of the caspase targets and in response to cellular stresses it detects and repairs DNA damage (Chaitanya et al., 2010).

Prostate and breast cancer are the most common and hormone-dependent malignancies in men and women, respectively (Bener et al., 2008; Safaei-Ghomi et al., 2009). The purpose of this study was to evaluate the effect of N. cataria on apoptosis process and its cytotoxic activity in both breast and prostate cancer cell lines

${ }^{1}$ Department of Pharmacognosy, ${ }^{2}$ Department of Pharmacodynamics and Toxicology, ${ }^{3}$ Department of Pharmaceutical Biotechnology, School of Pharmacy; Mashhad University of Medical Sciences, Mashhad, Iran*For correspondence: tayaraninz@mums.ac.ir 
that could be promising for treatment of these cancers in future. Cytotoxic activity of different extracts of the aerial parts of the plant (N. cataria) including methanol extracts, n-hexan, methylene chloride $(\mathrm{CH} 2 \mathrm{Cl} 2)$, ethyl acetate (EtOAc), n-butanol (n-BuOH), and $\mathrm{H} 2 \mathrm{O}$ fractions and the essential oil were compared on MCF-7, DU-145 and PC3 cells. Moreover, PI staining of treated cells and western blot analysis of proteins involved in the apoptosis cascade were studied to reveal the mechanism of cell death induced by the plant.

\section{Materials and Methods}

\section{Chemicals}

AlamarBlue ${ }^{\circledR}$ (resazurin) from Sigma (Saint Louis, MO, USA); RPMI-1640 and FBS were obtained from Gibco. All antibodies were bought from Cell Signaling technology (Boston, USA); ECL Western blotting detection reagent was purchased from Bio-RaD (USA); the fluorescent probe propidium iodide (PI), protease inhibitor cocktail (Sigma P8340), sodium citrate, Triton $\mathrm{X}-100$, phenyl methyl sulfonyl fluoride (PMSF) and Quanti Pro BCA Assay Kit were purchased from Sigma (Steinheim, Germany); all solvents as analytical grade used in this work were purchased from Merck, Germany.

\section{Plant Materials}

Aerial parts of N. cataria were collected in June 2013 from 1900 meters of altitude in a village called Reen, (km southwest of Bojnoord), North Khorasan province, northeast of Iran, and were identified by Souzani from the Herbarium of School of Pharmacy, Mashhad University of Medical Sciences, Mashhad, Iran where the voucher specimen (No:12055) of the plant was deposited. The extraction method was done according to previously reported protocol (Tayarani-Najaran et al., 2013) (Figure 1). The essential oil (EO) was prepared, using a Cleavenger type apparatus after $3 \mathrm{~h}$ hydrodistillation of the aerial parts $(100 \mathrm{~g})$ of N. cataria. The oil was passed over anhydrous sodium sulfate to obtain the dried slightly yellow colored oil.

Extracts and the EO were subjected to cytotoxic assay and the essential oil of the plant was subjected to GC and GC-MS analysis.

\section{Gas-Chromatography and Gas-Chromatography-Mass Spectrometry}

The GC analysis of EO was carried out by means of a Varian CP-3800 equipped with a FID detector, fused-silica column (CP-Sil 8CB, $50 \mathrm{~m} \times 0.25 \mathrm{~mm}$, film thickness 0.12 $\mathrm{m})$. The operating conditions were set as follows: oven temperature $50^{\circ} \mathrm{C}(5 \mathrm{~min}), 50^{\circ} \mathrm{C}-250^{\circ} \mathrm{C}\left(3^{\circ} \mathrm{C} / \mathrm{min}\right), 250^{\circ} \mathrm{C}$ (10 min); injector temperature $260^{\circ} \mathrm{C}$, split ratio $1: 5$, with carrier gas, $\mathrm{N} 2(2 \mathrm{ml} / \mathrm{min})$; detector temperature $280^{\circ} \mathrm{C}$.

The GC-MS analyses were conducted using a Agilent 5,975 apparatus with a HP-5ms column $(30 \mathrm{~m} \times 0.25 \mathrm{~mm}$ i.d., $0.25 \mu \mathrm{m}$ film thickness) interfaced with a quadruple mass detector and a computer equipped with Wiley $7 \mathrm{n} .1$ library; device setting were as follows :oven temperature $50^{\circ} \mathrm{C}(5 \mathrm{~min}), 50^{\circ} \mathrm{C}-250^{\circ} \mathrm{C}\left(3^{\circ} \mathrm{C} / \mathrm{min}\right), 250^{\circ} \mathrm{C}(10 \mathrm{~min})$;

injector temperature $250^{\circ} \mathrm{C}$; volume injection, 0.1 $\mu \mathrm{L}$; split ration, 1:50; carrier gas Helium at $1.1 \mathrm{ml} \mathrm{min}$; ionization potential, $70 \mathrm{eV}$; ionization current, $150 \mu \mathrm{A}$; ion source temperature, $250^{\circ} \mathrm{C}$; mass range, 35-465 mui.

The constituents of the oils were identified by calculation of their retention indices under temperature programmed conditions for n-alkanes (C8-C20) and the oil on a CP-Sil $8 \mathrm{CB}$ column. Identification of individual compounds was made by comparison of their mass spectra and retention indices (RI) with those authentic samples and those given in the literature. Quantification of the relative

Table 1. Chemical Composition of Essential Oil Obtained by Hydro-Distillation from Aerial Parts of N. Cataria

\begin{tabular}{|c|c|c|c|}
\hline $\mathrm{NO}$ & Compound & RI 1 & Percentage \\
\hline 1 & $\alpha$-pinene & 937.0 & $\mathrm{t} 2$ \\
\hline 2 & sabinene & 977.0 & $\mathrm{~T}$ \\
\hline 3 & $\beta$-pinene & 978.0 & 0.1 \\
\hline 4 & 1-octen-3-ol & 986.0 & $\mathrm{~T}$ \\
\hline 5 & 3-octanone & 991.0 & $\mathrm{~T}$ \\
\hline 6 & benzen acetaldehyde & $1,049.0$ & $\mathrm{~T}$ \\
\hline 7 & $\gamma$-terpinene & $1,063.0$ & $\mathrm{~T}$ \\
\hline 8 & 1-octanol & $1,078.0$ & $\mathrm{~T}$ \\
\hline 9 & $\alpha$-terpinolene & $1,103.0$ & 0.1 \\
\hline 10 & n-nonanal & $1,108.0$ & $\mathrm{~T}$ \\
\hline 11 & citronellal & $1,159.0$ & $\mathrm{~T}$ \\
\hline 12 & terpinen-4-ol & $1,180.0$ & $\mathrm{~T}$ \\
\hline 13 & $\alpha$-terpineol & $1,193.0$ & $\mathrm{~T}$ \\
\hline 14 & methyl salysilate & $1,195.0$ & 0.1 \\
\hline 15 & unknown & $1,199.0$ & 0.2 \\
\hline 16 & neral & $1,246.0$ & 0.1 \\
\hline 17 & trans-geraniol & $1,262.0$ & $\mathrm{~T}$ \\
\hline 18 & geranial & $1,276.0$ & 0.1 \\
\hline 19 & nepeta lactone (a steroisomer) & $1,377.0$ & 13.5 \\
\hline 20 & nepeta lactone (a steroisomer) & $1,378.0$ & 2.0 \\
\hline 21 & nepeta lactone (a steroisomer) & $1,379.0$ & 10.7 \\
\hline 22 & nepeta lactone (a steroisomer) & $1,429.0$ & 56.0 \\
\hline 23 & nepeta lactone (a steroisomer) & $1,436.0$ & 15.5 \\
\hline 24 & unknown & $1,454.0$ & 0.1 \\
\hline 25 & $\alpha$-humulene & $1,462.0$ & 0.2 \\
\hline 26 & (E)- $\beta$-farnesene & $1,468.0$ & 0.8 \\
\hline 27 & (E)- $\beta$-ionene & $1,494.0$ & $\mathrm{~T}$ \\
\hline 28 & 3Z-hexenyl benzoate & $1,577.0$ & $\mathrm{~T}$ \\
\hline 29 & caryophyllene oxide & $1,587.0$ & 0.2 \\
\hline 30 & humulene epoxide II & $1,612.0$ & $\mathrm{~T}$ \\
\hline 31 & benzyl benzoate & $1,768.0$ & $\mathrm{~T}$ \\
\hline \multirow[t]{8}{*}{32} & hexadecanoic acid & $1,973.0$ & 0.1 \\
\hline & Major Grouped Compounds & & \\
\hline & Monoterpene hydrocarbons & 0.3 & \\
\hline & Oxygenated monoterpenes & 98.1 & \\
\hline & Sespuiterpene hydrocarbons & 0.9 & \\
\hline & Oxygented sesquiterpenes & 0.2 & \\
\hline & Miscellaneous compounds & 0.3 & \\
\hline & Total identifie d & 99.8 & \\
\hline
\end{tabular}


Table 2. IC50 Values $(\mu \mathrm{g} / \mathrm{ml})$ for $\mathrm{MeOH}, \mathrm{n}-\mathrm{Hexane}$, $\mathrm{CH} 2 \mathrm{Cl} 2$, EtOAc, n-BuOH and $\mathrm{H} 2 \mathrm{O}$ Fractions and the Eessential oil of N. Cataria on PC3, DU-145 and MCF7 cells

\begin{tabular}{llll}
\hline & \multicolumn{2}{l}{ IC50 $(\mu \mathrm{g} / \mathrm{ml})$} & \\
Cell line & MCF-7 & PC3 & DU-145 \\
\hline Essential Oil & $>500.0$ & $>500.0$ & $>500.0$ \\
$\mathrm{H} 2 \mathrm{O}$ & $>500.0$ & $>500.0$ & $>500.0$ \\
$\mathrm{n}-\mathrm{BuOH}$ & $>500.0$ & $>500.0$ & $>500.0$ \\
$\mathrm{CH} 2 \mathrm{Cl} 2$ & $>500.0$ & $>500.0$ & $>500.0$ \\
EtOAc & $>500.0$ & 149.6 & $>500.0$ \\
n-Hexane & $>500.0$ & $>500.0$. & $>500.0$ \\
$\mathrm{MeOH}$ & $>500.0$ & $>500.0$ & $>500.0$ \\
\hline
\end{tabular}

amount of the individual components was performed according to the area percentage method without consideration of the calibration factor.

\section{Sample Preparation}

$500 \mathrm{mg} / \mathrm{ml}$ essential oil and $50 \mathrm{mg} / \mathrm{ml}$ extracts stock solutions were dissolved in DMSO. Then cells were treated with different concentrations $(15-500 \mu \mathrm{g} / \mathrm{ml})$ of stock after diluting the stock solutions in (RPMI-1640) medium.

\section{Cell Culture}

DU-145, PC3 (human prostate cancer cell lines) and MCF-7 ( breast cancer cell line) were bought from the Pasteur Institute (Tehran, Iran) and maintained at $37^{\circ} \mathrm{C}$ in a humidified atmosphere (90\%) containing 5\% CO2. Cells were cultured in RPMI-1640 with $10 \%$ (v/v) fetal bovine serum, $100 \mathrm{U} / \mathrm{ml}$ penicillin, and $100 \mu \mathrm{g} / \mathrm{ml}$ streptomycin.

\section{Cell Viability}

AlamarBlue ${ }^{\circledR}$ assay was performed to measure DU-145, PC3 and MCF-7 and cells viability. To screen cell viabilities, DU-145, PC3 and MCF7 (104 cells per well) were seeded in 96-well plate and were treated by various concentrations of essential oil and each fraction of N. cataria. After $48 \mathrm{~h}$ incubation, $1 \%$ of total well content alamarBlue ${ }^{\circledR}$ was added to each well and the absorbance was measured after $4 \mathrm{~h}$ of incubation, at $570 \mathrm{~nm}$ and 600 nm using Synergy H4 Hybrid Multi-Mode Microplate Reader (BioTek, Winooski, USA). The cytotoxicity of essential oil and extracts were determined as IC50, using Graph Pad Software (Graph Pad Prism 5 software) and presented as mean \pm SEM of three independent experiments with three replicates for each concentration of N. cataria extract.

\section{Apoptosis}

PI Staining

In order to detect apoptotic cells propedium iodide, a florescent DNA binding dye, was utilized. First, apoptotic cells become permeable with triton-X 100 so DNA fragments and are moved from apoptotic cells to the hypotonic buffer. Apoptotic cells exhibit low fluorescent intensity and appear before G1 peak in the flow cytometry histogram in comparison with the control unaffected cells (Nicoletti et al., 1991).
Aerial parts of Nepeta cataria $L$.

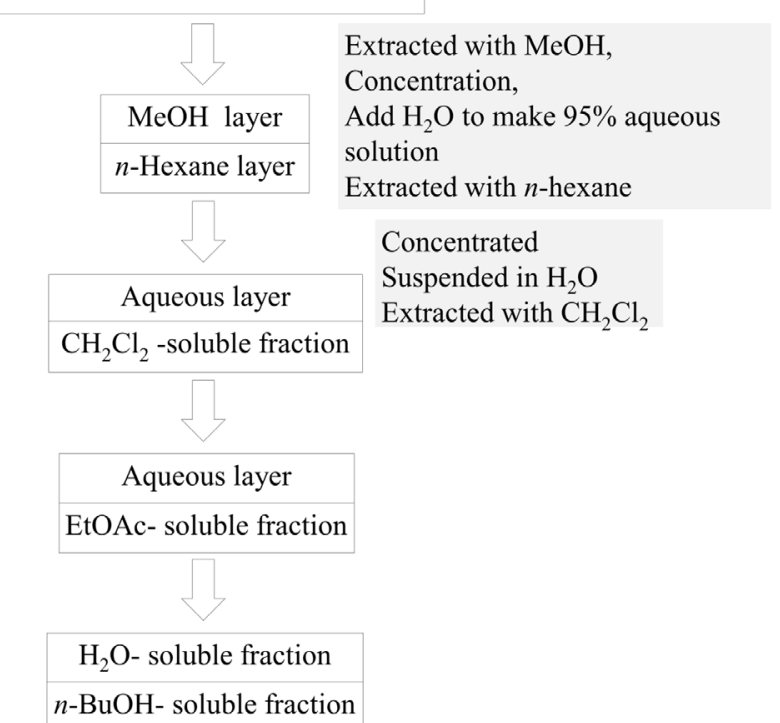

Figure 1. Schematic Partitioning of N. Cataria Between Different Fractions and Essential Oil Preparation

PC3 cells were seeded in a 24-well plate (105 cell per well) after $24 \mathrm{~h}$ treated with the fractions (EtOAc). Floating and adherent cells were collected and incubated at $4^{\circ} \mathrm{C}$ overnight in the dark with $500 \mu \mathrm{l}$ of a hypotonic buffer $(50 \mu \mathrm{g} / \mathrm{ml} \mathrm{PI}$ in $0.1 \%$ sodium citrate plus $0.1 \%$ Triton $\mathrm{X}-100)$.Flow cytometric analysis was performed by using a FACScan flow cytometer (Becton Dickinson). Around 10,000 events were counted with FACS (Nicoletti, 1991)

\section{Western Blotting Analysis}

PC3 cells were treated with different concentrations including $62.5,125$ and $250 \mu \mathrm{g} / \mathrm{ml}$ of the EtoAc extract of N. catariafor $48 \mathrm{~h}$. after that cells rinsed with cold PBS. The cell pellet was resuspended in a lysis buffer containing $50 \mathrm{mM}$ Tris- $\mathrm{HCl}$ (pH 7.4), $150 \mathrm{mM} \mathrm{NaCl}, 1 \%$ triton $\mathrm{X}-100,1 \mathrm{mM}$ EDTA, $0.2 \%$ SDS, $1 \%$ protease inhibitor cocktail and $1 \mathrm{mM}$ phenylmethylsulfonyl fluoride and then put on ice for $30 \mathrm{~min}$. centrifugation at $14000 \mathrm{rpm}$ for 20 min at $4^{\circ} \mathrm{C}$ was done (Hettich Universal 320R, Germany). Supernatant pull and protein content were measured by BCA protein assay kit (BioRad) with BSA as standard. Western blot analysis was performed on protein extracts from the pc3 cells for PARP, Caspase and Bax. Equal amounts of proteins were loaded to $12.5 \%$ SDS-PAGE $(\mathrm{w} / \mathrm{v})$.

After electrophoresis, proteins were transferred to a polyvinylidene fluoride (PVDF) membrane.

The primary antibodies were rabbit polyclonal anti-serum against caspase-3 (Cell Signaling, \#9, 661), Bax (Cell Signaling, \#2, 772), PARP (Cell Signaling \#9, 542) and rabbit monoclonal antiserum against b-actin, (Cell Signaling, \#4, 967).anti- rabbit IgG, HRP linked antibody (Cell Signaling, \#7, 074) were utilized as secondary antibodies. All protein bands normalized against b-actin.

Protein bands were detected using an enhanced chemiluminescence (Pierce ECL western blotting substrate) and Alliance gel doc. (Alliance.Gel doc, UK). 

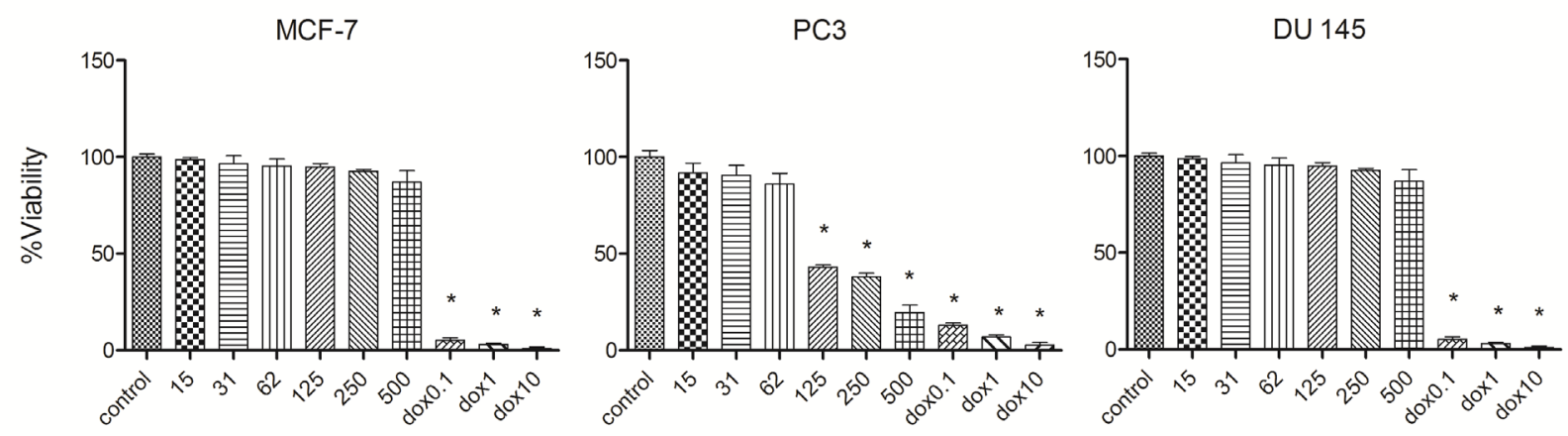

Concentration $(\mu \mathrm{g} / \mathrm{mL})$

Figure 2. The DU-145, PC3 and MCF-7 Cell Viability After Treatment with MeOH, n-Hexane, CH2Cl2, EtOAc, n$\mathrm{BuOH}$ and $\mathrm{H} 2 \mathrm{O}$ Extracts and the Essential Oil of N. Cataria. EtOAc Fraction Exhibited Cytotoxic Activity Against PC3. Values were Mean \pm SEM of at Least Three Independent Experiments, Each in Triplicates.

Images were analyzed and quantified using the Gel-Pro Analyzer v. 6. 0 Gel Analysis Software.

\section{Statistical Analysis}

One way analysis of variance (ANOVA) and Bonferroni's posthoc were used for data analysis. All results were expressed as mean \pm SEM and $p$ values below 0.05 were considered statistically significant.

\section{Results}

\section{Essential Oil Composition}

The 30 components were identified as volatile, representing $99.7 \%$ of EO composition after GC-MS analysis of the oil obtained from aerial parts of the N. cataria by hydro-distillation (Table 1 ). The grouped contents of the essential oil were determined as monoterpene hydrocarbons $0.3 \%$, oxygenated monoterpenes $98.1 \%$, sesquiterpene hydrocarbons $0.9 \%$, oxygenated sesquiterpens $0.2 \%$, and the miscellaneous $0.3 \%$. The major oil components of the essential oil were nepetalactone stereoisomers.

\section{Cytotoxicity of the Various Extracts of the N. cataria}

The cell viability of cancerous cells treated with different concentrations of $\mathrm{MeOH}$, n-hexane, $\mathrm{CH} 2 \mathrm{Cl} 2$, EtOAc, n-BuOH and $\mathrm{H} 2 \mathrm{O}$ extracts and the essential oil of $\mathrm{N}$. cataria $(15-500 \mu \mathrm{g} / \mathrm{ml})$ were monitored after 48 h. Only EtOAc extract of the plant could significantly decreased cell viability in PC3 cells, as a concentration dependent manner (Fig. 2). Doses inducing 50\% cell growth inhibition (IC50) against PC3 cells are presented in Table 2. doxorubicine $(1 \mu \mathrm{M})$ was used as a positive control.

\section{Role of Apoptosis \\ PI Staining}

Apoptosis was measured with PI staining following treatment with EtOAc extract of $\mathrm{N}$. cataria to detect the sub-G1 peak resulting from DNA breakdown. Sub-G1 peak as an indicative of apoptotic cells was induced in EtOAc extract of N. cataria treated cells, but not in the control cells. EtOAc extract of N. cataria treated cells showed a sub-G1 peak in PC3 cells in a concentration dependent manner that indicates the involvement of an
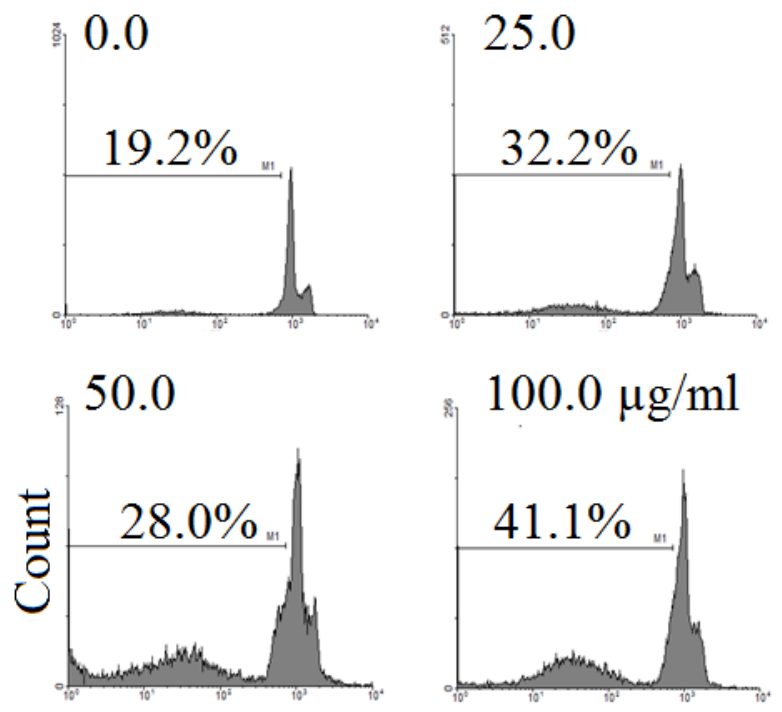

\section{Fluorescent intensity}

Figure 3. PI Staining and Flow Cytometry Analysis of EtOAc Fraction of N. Cataria on PC3 Cells.

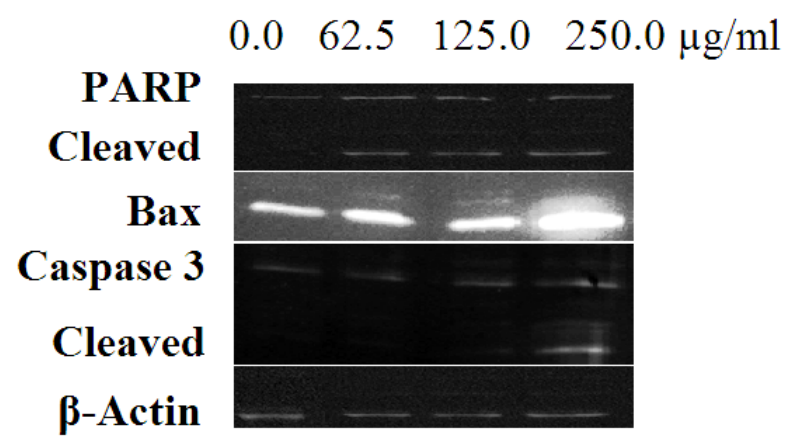

Figure 4. Proteolytic Cleavage of Poly (ADP-Ribose) Polymerase (PARP) and Caspase 3 to Active Form, and Increased Level of Bax Protein After $48 \mathrm{~h}$ Exposure to EtOAc Extract of N. Cataria (62.5, 125 and $250 \mu \mathrm{g} /$ $\mathrm{ml})$ in PC3 cells. $\beta$-Actin was Used as a Loading Control. All Western Blots were Representative of 3 Independent Experiments. 
apoptotic process in EtOAc extract -induced cell death (Figure 3).

\section{Effect of N. cataria on apoptotic proteins (PARP, Bax and caspase 3)}

Cleavage of $116 \mathrm{kDa}$ PARP to 89 and $24 \mathrm{kDa}$ fragments consider as the sign of apoptosis (Elmore, 2007). Western blotting analysis showed that in PC3 cells treated with EtOAc (48 h) caspase 3 and PARP were cleaved to active form (Figure 4). The level of Bax protein has an important role in the induction of apoptosis via the mitochondrial pathway. Protein expression of Bax enhanced in PC3 cells treated with EtOAc extract of N. cataria (Figure 4).

\section{Discussion}

This study was conducted to verify the cytotoxic effect of methanol extracts, n-hexan, $\mathrm{CH} 2 \mathrm{Cl} 2$, EtOAc, n-BuOH, and $\mathrm{H} 2 \mathrm{O}$ extracts and $\mathrm{EO}$ obtained from the aerial parts of the N. catariaon on PC3, DU-145 (prostate cancer) and MCF-7 cells (breast cancer).

Obtained EO from N. cataria contains 32 compounds among which 30 of the total oil mixtures were identified and listed in Table 1. Nepetalacton with 97.7 percent was identified as the major component.

There are several reports on cytotoxic activity of some genus of Nepeta. Baloch et al. reported crude methanol extract and crude acetone fraction of $\mathrm{N}$. praetervisa have maximum cytotoxic effect on brine shrimp with ED50 values of 0.60 and $0.56 \mu \mathrm{g} / \mathrm{ml}$ respectively (Baloch et al., 2013). In another study, ethyl acetate extract of N. suavis Stapf. showed high cytotoxic effect against brine shrimp larvae with LD50 of $41.3 \mu \mathrm{g} / \mathrm{ml}$ (Rehman et al., 2015).

EtOAc extract of the N. cataria showed the lowest IC50 value on PC3. Extraction with different solvent might remove compounds of the opposite polarity in the obtained extract. Since EtOAc is a semi-polar solvent it seems semi-polar compounds are responsible for the cytotoxic activity.

Shakeri et al. studied the cytotoxic effect of EO obtained from N. ucrainica ssp. kopetdaghensis on human ovarian carcinoma A2780 and breast adenocarcinoma MCF-7 cell lines and reported the IC50 values less than $50 \mu \mathrm{g} / \mathrm{ml}$ for both cells. The most abundant component of essential oil in this species was germacrene D (53.0\%) (Shakeri et al., 2014).

Cytotoxic evaluations of essential oils of N. glomerata against the renal adenocarcinoma cell line revealed $48 \%$ of inhibition of proliferation at $100 \mu \mathrm{g} / \mathrm{ml}$. The main substances of the essential oil of $\mathrm{N}$. glomerata were $\alpha$-pinene, spathulenol and carvacrol. The EO obtained from N. cataria with active antimicrobial properties has been analyzed previously and nepetalactone was reported as the main component (Zomorodian et al., 2012; Zomorodian et al., 2013). According to the studies mentioned above, it is clear that nepetalactone form the major components in the essential oil of $\mathrm{N}$. cataria.

The cytotoxic evaluations of methanol extract, n-hexane, $\mathrm{CH} 2 \mathrm{Cl} 2$, EtOAc, n-BuOH, and $\mathrm{H} 2 \mathrm{O}$ fractions and the essential oil obtained from the aerial parts of the
N. cataria on PC3, DU-145 and MCF-7 cells showed the potent cytotoxic activity of EtOAc extract on PC3 cells. After that apoptosis induction was verified in treated cells following observation of sub G1 peak in flow cytometery histograms and increased in pro-apoptotic Bax protein and cleavage of PARP. Lack of the protective effect of PARP promotes apoptosis of cells which was reported previously for anticancer drugs (Chaitanya et al., 2010 ).

It has been reported some botanical families have isoflavones that mimic the function of estrogenic compounds and contain steroidal structure (Kim et al., 2008). In this regard, N. cataria L. contain $\beta$-sitosterol which is similar to human steroids has been used to relieve the complications related postmenopausal syndrome (Dweck, 2006). Several studies suggested estrogens and their receptors (ERs) involved in progression and control cell growth in prostate and breast cancers (De Mayo et al., 2002; Kuiper et al., 1996; Prins et al., 2001). Since the expression level of the ER $\alpha$ and ER $\beta$ are higher in PC3 compare to DU145 cells (Linja et al., 2003), so it is expected that PC3 cells, as estrogen sensitive cell, show greater response to the phytoestrogens of the plant extracts. As expected in our study, more cytotoxic effect was observed in PC3 cells. Both DU-145 and PC3 cells with same androgen receptors profile $\left(\mathrm{AR}^{-}\right)$introduced as castration-resistant prostate but there was some evidence reported that over-passaged $\mathrm{PC} 3$ cells can change its negative androgen receptors profile to positive ( $\mathrm{PC} 3 \mathrm{AR}+$ ) (Buchanan et al., 2004). Therefore, we hypothesize more cytotoxic activity of $\mathrm{N}$. cataria on PC3 cells in comparison with DU145 $\mathrm{AR}^{-}$cells might be due to different response of cells to sex hormones.

It is found that apoptosis is the preferred mechanism of cell death against chemotherapy agents (Hannun, 1997). In this study, EtOAc extract of N. cataria could enhance the expression level of Bax protein and cleavage of PARP on PC3 cell line. In apoptotic cells due to the presence of fragmented DNA, lower fluorescence intensity of PI stained cells were absorbed and appeared as a sub-G1 peak in the histogram of flow cytometry. This effect was dose-dependent; so by increasing the percentage of apoptotic cells, the AUC of sub G1 peak increased. Since cells treated with increasing concentration of EtOAc fraction of N. cataria showed sub G1 peak, apoptosis was determined as the key mechanism of cell death in cytotoxicity of this plant. In conclusion, the semi polar EtOAc extract of N. cataria induces apoptosis in pc 3 cells compare to DU-145 cells and further analytical assays are suggested to identify the active phytochemicals possess cytotoxic activity.

\section{Acknowledgement}

The authors would like to thank Mr. M. Malaekeh for his assistance in flow cytometry. This work was supported by grants (No. 921271) from Research Affairs of Mashhad University of Medical Sciences as a part of a Pharm. D. thesis. The authors have declared no conflict of interest. 


\section{References}

Baloch N, Nabi S, Bashir S, Al-Kahraman Ym (2013) In vitro antileishmanial, cytotoxic activity and phytochemical analysis of Nepeta Praetervisa leaves extract and its fractions. Int J Pharm Pharm Sci, 5, 475-8.

Baser K, Kirimer N, Kurkcuoglu M, Demirci B (2000) Essential oils of Nepeta species growing in Turkey. Chem Nat Compd, 36, 356-9.

Bener A, Ayub H, Kakil R, Ibrahim W (2008) Patterns of cancer incidence among the population of Qatar: a worldwide comparative study. Asian Pac J Cancer Prev, 9, 19-24.

Buchanan G, Craft PS, Yang M, et al. (2004) PC-3 cells with enhanced androgen receptor signaling: A model for clonal selection in prostate cancer. Prostate, 60, 352-66.

Chaitanya GV, Steven AJ, Babu PP (2010) PARP-1 cleavage fragments: signatures of cell-death proteases in neurodegeneration. J Cell Commun Signal, 8, 31 .

De Mayo FJ, Zhao B, Takamoto N, Tsai SY (2002) Mechanisms of action of estrogen and progesterone. Ann N Y Acad Sci, 955, 48-59.

Duke JA ( 2001) Handbook of Medicinal Plants, Boca Raton. CRC press, 325-7.

Dweck AC (2006) Isoflavones, phytohormones and phytosterols. $J$ Appl Cosmetol, 24, 17-33.

Elmore S (2007) Apoptosis: a review of programmed cell death. Toxicol Pathol, 35, 495-516.

Handjieva NV, Popov SS, Evstatieva LN (1996). Constituents of essential oils from Nepeta cataria L., N. grandiflora MB and N. nuda L. J Essent Oil Res, 8, 639-43.

Hannun YA (1997) Apoptosis and the dilemma of cancer chemotherapy. Blood, 89, 1845-53.

Jamzad, Z (2012) Lamiaceae. in: Flora of Iran. Assadi, M., ed. No.76, Tehran, Research Institute of Forests and Rangelands, 454-609.

Kim IG, Kang SC, Kim KC, Choung ES, Zee OP (2008) Screening of estrogenic and antiestrogenic activities from medicinal plants. Environ Toxicol Pharmacol, 25, 75-82.

Kuiper G, Enmark E, Pelto-Huikko M, Nilsson S, Gustafsson J-A (1996) Cloning of a novel receptor expressed in rat prostate and ovary. P Natl Acad Sci, 93, 5925-30.

Linja MJ, Savinainen KJ, Tammela TL, Isola JJ, Visakorpi $\mathrm{T}$ (2003) Expression of ER $\alpha$ and ER $\beta$ in prostate cancer. Prostate, 55, 180-6.

Nicoletti I, Migliorati G, Pagliacci M, Grignani F, Riccardi C (1991) A rapid and simple method for measuring thymocyte apoptosis by propidium iodide staining and flow cytometry. J Immunol Methods, 139, 271-9.

Prins GS, Birch L, Couse JF (2001) Estrogen imprinting of the developing prostate gland is mediated through stromal estrogen receptor alpha: studies with alphaERKO and beta ERKO mice. Cancer Res, 61, 6089-97.

Rehman NU, Begum N, Ali L, et al. (2015) Lipid eroxidation, antiglycation, cytotoxic, phytotoxic, antioxidant, antiplatelet and antimicrobial activities of Ajuga bracteosa against various pathogens. Pak J Bot, 47,1195-7.

Rigano D, Arnold NA, Conforti F, et al. (2011) Characterisation of the essential oil of Nepeta glomerata Montbret et Aucher ex Bentham from Lebanon and its biological activities. Nat prod Res, 25, 614-26.

Safaei-Ghomi J, Djafari-Bidgoli Z, Batooli H (2009) Volatile constituents analysis of Nepeta cataria from central Iran. Chem Nat Compd ,45, 913-5.

Shakeri A, Khakdan F, Soheili V, et al (2014) Chemical composition, antibacterial activity, and cytotoxicity of essential oil from Nepeta ucrainica L. spp. kopetdaghensis. Ind Crop Prod, 58, 315-21.
Tayarani-Najaran Z, Mousavi SH, Tajfard F, et al (2013) Cytotoxic and apoptogenic properties of three isolated diterpenoids from Salvia chorassanica through bioassay-guided fractionation. Food Chem Toxicol, 57, 346-51.

Zomorodian K, Saharkhiz MJ, Rahimi MJ, et al (2013) Chemical composition and antimicrobial activities of essential oil of Nepeta cataria L. against common causes of oral infections. J Dent, 10, 329-37.

Zomorodian K, Saharkhiz MJ, Shariati S, et al (2012) Chemical composition a Table 1:Chemical composition of essential oil obtained by hydro-distillation from aerial parts of N. cataria. food-borne infections, ISRN Pharmacol, 6, 1-6. 